\title{
濾紙 BPB 染色法による疲労尿蛋白測定法に関する研究

\author{
Studies on the Quantitative Method of Protein in Fatigued \\ Urine by means of Staining Urine Spot on the \\ Filter Paper with Brom-phenol-blue
}

\author{
岡山大学医学部公衆衞生学教室 (主任 大田原一祥教授) \\ 緒 方正名 \\ Masana Ogata \\ Department of Public Health, School of Medicine, Okayama University \\ (Director: Prof. K. Ohtahara)
}

\begin{abstract}
緒言
尿による疲労判定法として疲労尿中に現われる蛋白質 を定量する方法は古くから㧈てなわれている。緒方教 授, 大田原教授, 岡村氏 ${ }^{11}$ らは疲労尿を稀釈し抗人血清 家鬼血清と重層するととにょり尿中に排泄される蛋白質 を定量し, 疲労度を測定する方法を発表した。また石川 氏2) らは Sulfosalicyl 酸液や Spiegler 氏試薬による疲 労尿蛋白の定量法を発表している。

一方, 滤紙電気泳動法飞抢いて Kunkel, Tiselius ${ }^{3)}$ 万 核泳動後の Albumin, $\alpha-, \beta-, \gamma$-Globulin 分屑安定量する. 目的で泳動後の濾紙を BPB酶酸, 昇永溶液で染色し たのち，2\%酢酸で非結合色素を除去する方法を考案し た。

外塚 ${ }^{4}$ は各種疾患汇よる蛋白尿す;定量に滤紙法を応用 している。

著者は滤紙 BPB 染色法を用いて疲労尿蛋白質の定量 そ成功したのでここに報告する。
\end{abstract}

\section{実験方法}

\section{1) 疲労尿の採取}

サッカー試合前後尿を採取し実験に使用した。

\section{2) 润紙染色法}

東洋滤紙 No. 50 亿上記疲労尿の $0.02 \mathrm{ml}$ を滴下し, 自 然乾燥する。急ぐ場合は電熱器上で乾燥する。ついで BPB 染色液 (BPB $0.05 \mathrm{~g}$, 昇永 $1 \mathrm{~g}$, 酶酸 $2 \mathrm{ml}$ 蒸 溜水に溶解し $1 l$ としたもの) 中で 60 分間染色後, $2 \%$ 酢酸溶液で数回洗條して蛋白汇結合していない色素を除
去し自然乾燥する。脱色後の spot の薄い場合は, アン モニアガス上に濾紙を置くと滤紙がアルカリ性となる ために BPB が青変し, spotがさらに明確に現われ る。

3）濾紙尿蛋白定量法

a) 因眼による測定

日立製蛋白計または FolinのTyrosine 法5)であらか じめ人血清の蛋白濃度を測定し, 稀釈して $4 \%$ 液を作成 して原液とする。ついで原液を 倍数稀釈してその各液 $0.02 \mathrm{ml}$ を滤紙上に滴下し前述の方法で染色固定したも のを標準色度系列（第3図A）とする。尿の spot は標 準系列と比較してとれと等しい spot の栖準系列の濃度 を尿蛋白湟度とする。

b) 濾紙光度計による測定

標準系列の spot を有する滤紙を流動パラフィンで半 透明としたのちに滤紙光電光度計で一定の滤紙幅ごとに 吸光度を求める。第 1 図A はてのょうにして求めた吸光 度曲線である。この吸光度曲線の面積を面積計を用いて 定量すると峯の面積が蛋白濃度に比例する。すなわち第 2 四に示されるごとく $4 \%$ 以下の範囲では蛋白濃度と吸 光度面積との関係は直線で表示される。被梌尿は吸光度 曲線の面積値を第 2 四の検量直線活入して尿蛋白濃度 を算出する。

\section{4) Kingsbury-Clark 法}

試験管に尿 $1 \mathrm{ml}$ を入れ，とれに $3 \%$ Sulfosalicyl 酸 $3 \mathrm{ml}$ を加える。標準系列として既知濃度血清系列 $1 \mathrm{ml}$ に $3 \%$ Sulfosalicyl 酸 $3 \mathrm{ml}$ を加えた液をつくり, 両者 の混濁を肉眼で比較し尿蛋白濃度を決定する。 
第 1 図 澜紙法による疲労尿蛋白濃度測定法

(A) ' 人血清標準濃度列

(BPB 染色 $0.02 \mathrm{cc}$ 東洋濾紙 No. 50 )

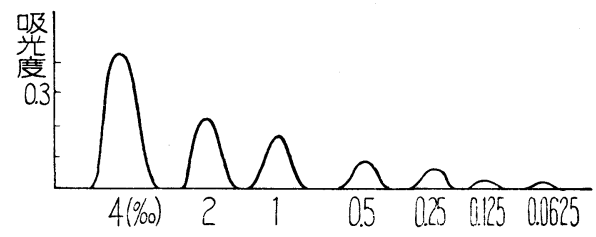

（B）疲労尿（サッカー）
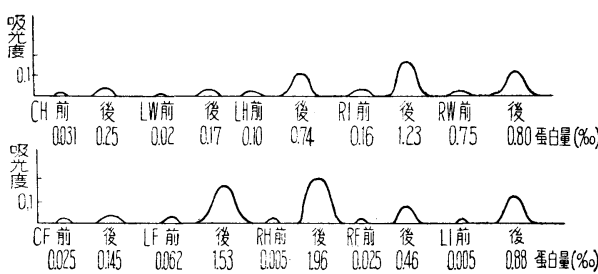

\section{5) Exton 法"}

尿 $1.0 \mathrm{ml}$ に水 $4.0 \mathrm{ml}, 2 \%$ アラビヤゴム $1.0 \mathrm{ml}, \mathrm{Ex}-$ ton 試薬 $5.0 \mathrm{ml}$ を添加乙 10 分後分光光電光度計（波長 $660 \mathrm{~m} \mu)$ で測定する。検量曲線は上述の原尿 $1.0 \mathrm{ml}$ の 代りに既知血清稀採系列 $1.0 \mathrm{ml}$ を加えた系を用いて吸 光度を測定して作製する。

\section{6) 尿微量蛋白測定法}

緒方-大田原氏法1) に準じて扢こなつた。

\section{実験結果}

第 3 図A は標準色度系列，B各ポジションに招ける サッカー選手試合前後尿の染色像であり，一見して試合

\section{第 2 図人血清標準源度曲線（核紙法）}

BPB 染色, $0.02 \mathrm{cc}$, 東洋濾紙 No. 50

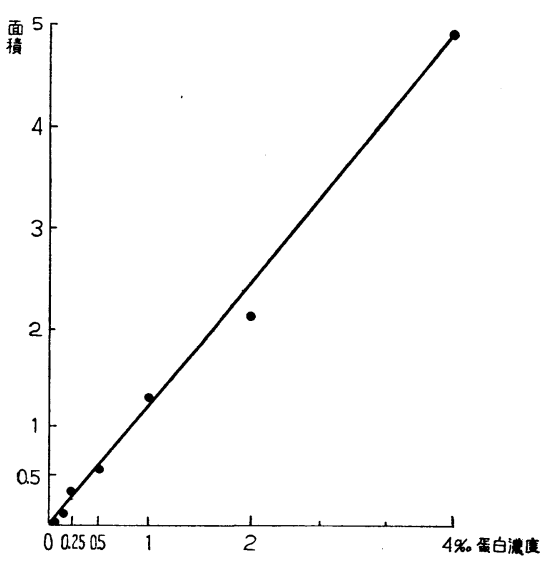

第 1 表 各種蛋白測定法による運動

疲労尿測定值 (サッカー)

\begin{tabular}{|c|c|c|c|c|c|c|}
\hline \multirow{2}{*}{\multicolumn{2}{|c|}{ 位置 }} & \multicolumn{2}{|c|}{ 濾 紙 法 } & \multirow{2}{*}{$\begin{array}{c}\text { Exton 法 } \\
(\%)\end{array}$} & \multirow{2}{*}{$\begin{array}{l}\text { Kingsbury- } \\
\text { Clark 法 }(\%\end{array}$} & \multirow{2}{*}{\begin{tabular}{|} 
緒方法 \\
抗原仾
\end{tabular}} \\
\hline & & 肉眼 $(\%)$ & 面積測定 & & & \\
\hline $\mathrm{LF}$ & & $\begin{array}{l}0.125 \\
2.0\end{array}$ & $\begin{array}{l}0.062 \\
1.53\end{array}$ & $\begin{array}{l}0.01 \\
2.1\end{array}$ & $\begin{array}{l}0.016 \\
1.0\end{array}$ & $\begin{array}{r}66 \\
128\end{array}$ \\
\hline $\mathrm{CF}$ & 前 & $\begin{array}{l}0.0625 \\
0.125\end{array}$ & $\begin{array}{l}0.025 \\
0.145\end{array}$ & $\begin{array}{l}0.062 \\
0.50\end{array}$ & $\begin{array}{l}0.03 \\
0.06\end{array}$ & $\begin{array}{l}16 \\
32\end{array}$ \\
\hline $\mathrm{RF}$ & $\mid$\begin{tabular}{|} 
前 \\
後
\end{tabular} & \begin{tabular}{|l|}
0.0625 \\
0.5
\end{tabular} & $\begin{array}{l}0.025 \\
0.46\end{array}$ & $\begin{array}{l}0.50 \\
0.80\end{array}$ & $\begin{array}{l}0.06 \\
0.50\end{array}$ & $\begin{array}{l}16 \\
32\end{array}$ \\
\hline LH & 前 & $\begin{array}{l}0.0625 \\
0.75\end{array}$ & $\begin{array}{l}0.10 \\
0.74\end{array}$ & $\begin{array}{l}0.30 \\
0.70\end{array}$ & $\begin{array}{l}0.008 \\
0.50\end{array}$ & $\begin{array}{r}4 \\
64\end{array}$ \\
\hline LI & 前 & $\begin{array}{l}0.03125 \\
1.0\end{array}$ & $\begin{array}{l}0.005 \\
0.88\end{array}$ & $\begin{array}{l}0 \\
1.04\end{array}$ & $\begin{array}{l}0.06 \\
1.0\end{array}$ & $\begin{array}{l}32 \\
64\end{array}$ \\
\hline $\mathrm{HC}$ & 前 & $\begin{array}{l}0.0625 \\
0.25\end{array}$ & $\begin{array}{l}0.031 \\
0.25\end{array}$ & $\begin{array}{l}0 \\
0.34\end{array}$ & $\begin{array}{l}0.12 \\
0.25\end{array}$ & $\begin{array}{r}4 \\
32\end{array}$ \\
\hline $\mathrm{RH}$ & 前 & $\begin{array}{l}0.03125 \\
3.0\end{array}$ & $\begin{array}{l}0.005 \\
1.96\end{array}$ & $\begin{array}{l}0 \\
3.20\end{array}$ & $\begin{array}{l}0.031 \\
2.0\end{array}$ & $\begin{array}{r}8 \\
128\end{array}$ \\
\hline RI & $\begin{array}{l}\text { 前 } \\
\text { 後 }\end{array}$ & \begin{tabular}{|l|}
0.0625 \\
1.0
\end{tabular} & $\begin{array}{l}0.16 \\
1.23\end{array}$ & $\overline{1.50}$ & $\begin{array}{l}0.03 \\
1.0\end{array}$ & $\begin{array}{r}16 \\
256\end{array}$ \\
\hline RW & 前 & $\begin{array}{l}0.125 \\
1.0\end{array}$ & $\begin{array}{l}0.75 \\
0.80\end{array}$ & $\begin{array}{l}0.50 \\
0.42\end{array}$ & $\begin{array}{l}0.03 \\
0.50\end{array}$ & $\begin{array}{r}16 \\
256\end{array}$ \\
\hline LW & \begin{tabular}{|} 
前 \\
後
\end{tabular} & $\begin{array}{l}0.03125 \\
0.125\end{array}$ & $\begin{array}{l}0.02 \\
0.17\end{array}$ & $\begin{array}{l}0.70 \\
1.14\end{array}$ & $\begin{array}{l}0.016 \\
0.06\end{array}$ & $\begin{array}{r}4 \\
32\end{array}$ \\
\hline
\end{tabular}

第 3 図（A） 血清標準系列

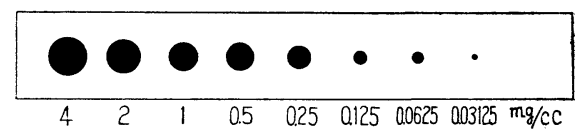

（B） 運動疲労尿（サッカー）

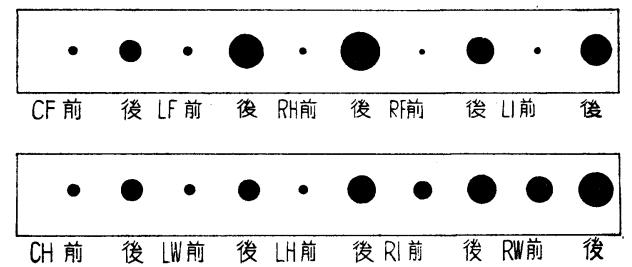

後尿は前尿に比して spot の増大と染色性の増加のある ことが認められる。疲労尿染色像を標準色度系列と比較 して測定した価は第 1 表第 2 行〔滤紙法肉眼（\%) の 項了に記載されている。第 1 図AおよびBは標準色度系 列の spot と疲労尿の spot 滤紙光度計を用いて測定 した吸光度曲線を示す。また面積測定法にょる測定值 は第 1 表第 3 行〔㵽紙法面積測定の項〕に記載されてい る。また第 4 行に同時に抢てなつた Exton 法による尿 蛋白量を，さらに第 5 行には Kingsbury-Clark 法によ る尿蛋白量を, 第 6 行には尿微量蛋白測定法" k小る尿 蛋白量を示している。 
第 4 図の白点はサッカー試合後尿の尿蛋白の定量にお いて横軸に Exton 法, 縦軸に面積測定による測定值を 記入した蛋白定量值の比較図であり, 両法で測定した価 はよい一致を示す。第 4 図の黒点は横軸に KingsburyClark 法, 縦軸に肉眼比色法を用いた場合の蛋白定量值 を比較したものであつて, 両法の測定值は拣とんど一致 するが, 肉眼比色法による BPB 染色法の方が Kingsbury-Clark 法ょり多少高く現われる㑯向を有する。濾 紙法の測定值と尿微量蛋白測定法の測定值とはまた流 比例法の関係を示している。

\section{第 4 図 Exton 法と 㧚紙法光度計定量值 なよび Kingsbury-Clark法と滤紙法肉眼定量值の比較}

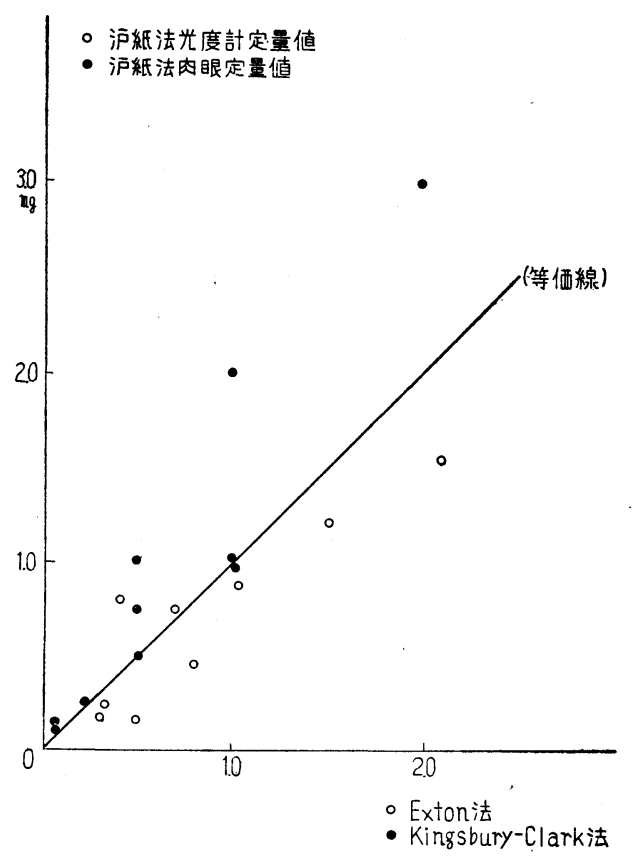

考按

\section{1） BPB 法の感度}

本法の感度は人血清の約 $1: 1,000 \quad(0.07 \%)$ まで検 出できる。アンモニアガスを通じて増感処理をおてなえ 浽約 $1 ： 10.000$ (0.007 \%) まで検出できる。

この方法は抗人血清家鬼血清を 用いた 緒方一大田原氏 尿微量蛋白測定法 ${ }^{11}$ の感度, 人血清稀釈 $1: 100,000 \mathrm{~K}$ は及ばないが,アンモニアガス処理の場合は Sulfosalicyl 酸法の感度 $1: 5,000$ とほとんぞ同等末たはそれ以上で あり，正常尿 (疲労前尿) の㴗とんどがアンモニア増感 処理をおこなえば定量可能である。

\section{2） BPB 法の正確度}

\section{a. 肉眼による判定}

被検尿の蛋白濃度が低い場合には光電光度計を使用し た場合より判定しやすい。またその測定結果は光電光度 計による測定成績と大体一致する。倍数稀釈標準色度系 列をの比較洼では尿蛋白の濃度比が $1 / 2$ 以上となつた場 合の測定はきわめて容易である。

b. 濾紙光電光度計による判定

蛋白量 $4 \%$ より $0.0625 \%$ の範囲では蛋白濃度と吸光度 曲線の囲む面積とは潘活直線関係を示し, 疲労前後尿の 濃度の範囲でば源とんぞこの蛋白量の範囲に 含ま れる が，尿蛋白質がさらにこれを超える場合には稀釈した試 料を滤紙上に滴下し測定した濃度值に稀釈度を乗じて蛋 白量学算出すればょい。上述の濃度の範囲では滤紙光電 光度計を用いた方が肉眼比色法より正確な測定結果を得 ることができる。

\section{3) BPB 法の本体}

Anderson 氏法8)を用い精製したムコ蛋白 $\mathrm{A}_{1}, \mathrm{~A}_{2}$ お よび本田のタルク吸着法9,10) による Donaggio 陽性物質 $1 \mathrm{mg} / \mathrm{ml}$ 液を $0.02 \mathrm{ml}$ 滤紙上に滴下し BPB 染色液で 染色した場合にはこれらのムコ蛋白は染色されるが昇承 に溶解するために滤紙上に固定されない。それ故に本反 応陽性物質は漂とんぞ尿ムコ蛋白を含まない尿蛋白質に 限局されるょうである。Sulfosalicyl 酸法では尿蛋白の 鿌かにアルブモーゼがわずかに反応しアルブモーゼ法反 灾後加熱によつて消失するといわれているが，その量は きわめて少量であり，大部恃尿蛋白質によるといわれて いる。尿微量蛋白測定法に扮いても抗人血清家鬼血清と 沈降反応を生ずる物質は拣とんぞ大部は血清蛋白質で一 部血清ムコ蛋白質抒よび尿ムコ蛋白（例えば Tamm 氏 ムコ蛋白) などを含むようである。それ故 BPB 法と Sulfosalicyl 酸法 (Kingsbury-Clark 法抢よびExton 法) 抢よび尿微量蛋白測定法の測定值が比例する事実はとの 点からも明らかな事実である。また著者らの研究では Donaggio 反心值と Sulfosalicyl 酸法による定量值执よび 尿微量蛋白測定值注有意な相関を示すので, BPB定量值 もまた Donaggio 反応值と併行して変動するのではない かと推定される。な扮 Donaggio 反応陽性物質と血清蛋 白質との関係については著者らの研究 ${ }^{12-15)}$ がある。

\section{4） BPB 法の利点}

Kingsbury-Clark 法では測定どとに血清の標潐系列を つくら权ばならぬ不便があるが，本法に打ける標準色度 系列は保存が可能であるから尿の spot の久で定量する ことが可能である。また測定には濾紙を用いるために試 験管を必要としない。試料の運搬に便利であり，かつ大 
量の試料を一時に染色し測定できるために産業疲労, ス ポーツ疲労などのように多数の試料の測定を一時に抗こ なうに適している方法と思われる。

\section{結論}

1）著者はサッカー試合前後の尿蛋白测定法として滤 紙 BPB 染色法を用い，疲労尿蛋白測定法として本法が 有効であることを認めた。

2） BPB 染色法の反応物質は尿中に排泄される血清 蛋白質であり，尿ムコ蛋白中タルク吸着法で分離した Donaggio 反忘陽性物質拉よび Anderson 沬により分離 した尿ムコ蛋白は染色液中に溶出されるため固定されず 本染色反応は陰性を示した。

3）滤紙法による尿蛋白の定量成績决抗人血清家鬼血 清による尿微量蛋白測定法, Sulfosalicyl 酸法（Exton 法, Kingsbury-Clark 法)の定量結果とほとんぞ等しい 成績を得ることができた。

4）本法は@試料がきわめて少量である点，標準色 度系列の保存が可能である点，@多量の試料を一時に処 理できる点，@試料の運搬掞よび保存が可能である点な ぞに扔いて尿蛋白測定法による疲労判定法として優れた 方法であると思われる。

終りと臨み本論交の御校閲を賜わつを恩師大田原一祥 教授に謹んで感謝の意を表す。

本論交の要旨は昭和 32 年 7 月第 27 回日本衛生学会総 会 ${ }^{11}$ K打いて発表した。

\section{交献}

1) 緒方益雄 - 大田原一祥・岡村岩男 : 疲労判定法, p. 61 , 学術研究会議疲労研究会編.

2) 石川知福 : 疲労判定法, p. 72 . 学術研究会議疲 労研究会編.

3) Kunkel, H. G. \& Tiselius, A. : J. Gen. Physiol., 35, 89, 1951.

4）外塚岩太郎・神村瑞夫：日本医事新報, No. 627 $\sim 656,1929$.

6) Kingsbury-Clark: J. Lab. Clin. Med., 11, 981, 1926.

7) Exton: J. Lab. Clin. Med., 10, 722, 1925.

8) Anderson, A. J. \& Maclagan, N. F.: Biochem. J., 59 (4) : 638, 1955.

9) 本田良行 : 十全医学会雑誌, 56( 1 ) : 16, 1954.

10) 本田良行 : 体力科学, $1,161,1951$.

11) 緒方正名 : 日本衛生学雑誌, Vol. 12, No. 2, p. $166,1957$.

12）緒方正名・望月義夫：日本衞生学雑誌, Vol. 13, No. 2, p. 181, 1958.

13）緒方正名・望月義夫：日本衛生学雑誌, Vol. 13, No. 2, p. 188, 1958.

14）緒方正名・望月義夫 : 日本衛生学雑誌, Vol. 13, No. 2, p. 194, 1958.

15）緒方正名・望月義夫・那須昭三 : 体力科学, 印 刷中.

（受付：1958 年 8 月 1 日） 